Article

\title{
Saving Resources: SARS-CoV-2 Diagnostics by Real-Time RT-PCR Using Reduced Reaction Volumes
}

\author{
Sabine Bock ${ }^{1}$, Bernd Hoffmann ${ }^{2} \mathbb{D}$, Martin Beer ${ }^{2}$ and Kerstin Wernike ${ }^{2, *} \mathbb{D}$ \\ 1 Berlin-Brandenburg State Laboratory, 15236 Frankfurt, Germany; Sabine.Bock@Landeslabor-bbb.de \\ 2 Institute of Diagnostic Virology, Friedrich-Loeffler-Institut, 17493 Greifswald, Germany; \\ bernd.hoffmann@fli.de (B.H.); martin.beer@fli.de (M.B.) \\ * Correspondence: kerstin.wernike@fli.de
}

check for updates

Citation: Bock, S.; Hoffmann, B.; Beer, M.; Wernike, K. Saving Resources: SARS-CoV-2 Diagnostics by Real-Time RT-PCR Using Reduced Reaction Volumes. Diseases 2021, 9, 84 . https://doi.org/10.3390/

diseases 9040084

Academic Editor: Massimo Pieri

Received: 4 October 2021

Accepted: 11 November 2021

Published: 15 November 2021

Publisher's Note: MDPI stays neutral with regard to jurisdictional claims in published maps and institutional affiliations.

Copyright: (c) 2021 by the authors. Licensee MDPI, Basel, Switzerland. This article is an open access article distributed under the terms and conditions of the Creative Commons Attribution (CC BY) license (https:// creativecommons.org/licenses/by/ $4.0 /)$.

\begin{abstract}
Since the beginning of 2020, the betacoronavirus SARS-CoV-2 is causing a global pandemic of an acute respiratory disease termed COVID-19. The diagnostics of the novel disease is primarily based on direct virus detection by RT-PCR; however, the availability of test kits may become a major bottleneck, when millions of tests are performed per week. To increase the flexibility of SARS-CoV-2 diagnostics, three real-time RT-PCR assays listed on the homepage of the World Health Organization were selected and investigated regarding their compatibility with three different RT-PCR kits. Furthermore, the reaction volume of the PCR chemistry was reduced up to half of the original protocol to make the individual reactions more cost- and resource-effective. When testing dilution series of culture-grown virus, nearly identical quantification cycle values (Cq) were obtained for all RT-PCR assay/chemistry combinations. Regarding the SARS-CoV-2 detection in clinical samples, agreeing results were obtained for all combinations for virus negative specimens and swabs containing high to medium viral genome loads. In cases of very low SARS-CoV-2 genome loads $(\mathrm{Cq}>36)$, inconsistent results were observed, with some test runs scoring negative and some positive. However, no preference of a specific target within the viral genome (E, RdRp, or N) or of a certain chemistry was seen. In summary, a reduction of the reaction volume and the type of PCR chemistry did not influence the PCR sensitivity.
\end{abstract}

Keywords: SARS-CoV-2; COVID-19; coronavirus; diagnostics; virus detection; swab; real-time RT-PCR

\section{Introduction}

In late 2019, an outbreak of an acute respiratory disease of humans was reported in Wuhan, China [1]. The novel disease, named COVID-19 (coronavirus disease 2019), very rapidly evolved into a global pandemic [2], resulting in millions of infections in all corners of the world and more than four and a half millions deaths in just under two years of virus circulation [3]. As a causative agent of the pandemic, a betacoronavirus referred to as severe acute respiratory syndrome coronavirus 2 (SARS-CoV-2) was identified [4].

COVID-19 is characterized by mild to moderate respiratory symptoms including pneumonia that can develop into a severe or critical disease, with much higher fatality rates in the elderly or when certain underlying health conditions affecting the cardiovascular, respiratory, or immune systems exist [2]. Nevertheless, also asymptomatic infections occur frequently, and it has been estimated that virus transmission from asymptomatic or presymptomatic humans accounts for about half of all COVID-19 cases [5]. This might be in particular critical when asymptomatically infected health care workers transmit the virus into homes for the elderly or hospitals. Onward transmission can be substantially reduced by containment measures such as physical distancing and population-level movement restrictions [6-8].

The diagnostics of the novel disease is currently primarily based on the detection of viral antigen by rapid lateral flow tests or, more commonly, on SARS-CoV-2 genome by 
real-time reverse transcription polymerase chain reaction (RT-PCR) using oropharyngeal or nasopharyngeal swabs as sample material. To identify and isolate infected persons, millions of RT-PCR tests are carried out around the world [9]. Hence, COVID-19 not only overloads national health care systems but also seriously challenges diagnostic capacities when hundreds or thousands of tests need to be performed per day per laboratory $[2,9,10]$. Although a large number of in-house and commercial real-time RT-PCR assays have been developed and compared regarding their diagnostic performance within a very short time frame [11-16], the timely and comprehensive diagnostics might be impaired by supply shortage of the PCR chemistry, as the availability of test kits has become a major bottleneck. Having several widely used assays rely on the identical PCR chemistry [13] might further complicate the wide availability of the necessary reagents. Here, we investigated several real-time RT-PCR assays regarding their combinability with diverse PCR master mixes to increase the flexibility of SARS-CoV-2 PCR diagnostics. In addition, the total reaction volumes were reduced to make the individual reactions more cost- and resource-effective. The selected real-time RT-PCR assays target different genomic regions, further increasing the flexibility, but also the diagnostic specificity, e.g., when contaminations with synthetic control material based on individual viral genes occur, which is a phenomenon that seemed to be widespread in the early stage of COVID-19 diagnostics $[17,18]$. The SARS-CoV-2 specific real-time PCRs were combined with internal control (IC) assays, which is highly recommended as a quality control measure to avoid false-negative results.

\section{Materials and Methods}

\subsection{RNA Standard, Virus and Diagnostic Samples}

As a PCR standard, purified RNA of SARS-CoV-2 cell culture supernatant was used (stock concentration $1 \times 10^{4}$ copies per $\mu \mathrm{L}$; provided by Charité-Universitätsmedizin Berlin, Germany, via European Virus Archive goes global (EVAg), Ref-SKU: 026N-03889). A dilution series was prepared in RNA-safe buffer [19], and each dilution step was tested in three replicates. Samples containing genome concentrations near the presumed limit of detection $\left(1 \times 10^{1}\right.$ copies $/ \mu \mathrm{L}, 2 \times 10^{0}$ copies $/ \mu \mathrm{L}$ and $1 \times 10^{0}$ copies $\left./ \mu \mathrm{L}\right)$ were tested in six replicates as suggested previously [20].

The SARS-CoV-2 virus isolate 2019_nCoV Muc-IMB-1 (kindly provided by R. Woelfel, German Armed Forces Institute of Microbiology, Munich, Germany) was propagated in Vero E6 cells (L1062, collection of cell lines in veterinary medicine, Friedrich-LoefflerInstitut, Greifswald-Insel Riems, Germany). Nucleic acid from different virus preparations was extracted using the QIAamp Viral RNA Mini kit (Qiagen, Hilden, Germany), and all samples were tested in the reactions described below in duplicates.

A total of 93 human pharyngeal swabs originating from different German federal states were submitted for routine diagnostics (legal provisions defined by the German Infection Protection Act (IfSG)). Viral RNA was extracted using the NucleoMag VET kit (MACHERYNAGEL GmbH \& Co. KG, Düren, Germany) according to the supplier's recommendation.

\subsection{Real-Time RT-PCRs}

The real-time RT-PCR systems "IP4", "E-Sarbeco", and "CDC-N3" that are listed on the website of the World Health Organization (WHO) for the genome detection of SARS-CoV-2 [13] were selected and established in our laboratories. To increase the diagnostic accuracy, assays targeting different genomic regions were chosen. The real-time RT-PCR IP4 is based on the RNA-dependent RNA polymerase (RdRp) gene [13], while the assay E-Sarbeco targets the E gene coding region [21], and the assay CDC-N3 targets the nucleocapsid (N) gene [13]. At first, the IP4 assay was established as published in combination with the SuperScript III One Step RT-PCR kit (Thermo Fisher Scientific, Darmstadt, Germany; $882 €$ per 100 reactions) using the previously described reaction conditions [13] and $5 \mu \mathrm{L}$ RNA template. Thereafter, the reactions were modified by replacing the PCR chemistry by (1) the AgPath-ID One-Step RT-PCR Reagents kit (Thermo Fisher Scientific; $255 €$ per 100 reactions) or (2) the qScript XLT One-Step RT-qPCR ToughMix kit 
(Quantabio, Beverly, MA, USA; $211 €$ per 100 reactions). For a single reaction, the following components were merged to a master mixture: (1) $4.5 \mu \mathrm{L}$ RNase-free water, $12.5 \mu \mathrm{L} 2 \mathrm{x}$ RT-PCR Buffer, $1 \mu \mathrm{L} 25 \times$ RT-PCR enzyme mix, and $2 \mu \mathrm{L}$ of the respective primer/probe mix (600 nM for each primer and $200 \mathrm{nM}$ probe); (2) $5.5 \mu \mathrm{L}$ RNase-free water, $12.5 \mu \mathrm{L} 2 \mathrm{x}$ qScript XLT One-Step RT-qPCR ToughMix and $2 \mu \mathrm{L}$ of the respective primer/probe mix ( $600 \mathrm{nM}$ for each primer and $200 \mathrm{nM}$ probe). In both cases, $5 \mu \mathrm{L}$ of RNA template was added. In a next step, the volume of the master mixture was reduced, resulting in $10 \mu \mathrm{L}$ for a single reaction, and either $5 \mu \mathrm{L}$ or $2.5 \mu \mathrm{L}$ of RNA template was added. The real-time RT-PCRs were carried out using the thermal profiles listed in Table 1. The limit of detection (LOD) was calculated by using a web service funded by BVL (Berlin, Germany; https:/ / quodata.de/content/validation-qualitative-pcr-methods-single-laboratory (accessed on 2 November 2021)).

Table 1. Thermal profiles of the RT-PCR chemistry used in this study.

\begin{tabular}{|c|c|c|c|c|}
\hline Reaction Step & $\begin{array}{l}\text { SuperScript III One } \\
\text { Step RT-PCR Kit }\end{array}$ & $\begin{array}{c}\text { AgPath-ID } \\
\text { One-Step RT-PCR } \\
\text { Reagents Kit }\end{array}$ & $\begin{array}{c}\text { qScript XLT } \\
\text { One-Step RT-qPCR } \\
\text { ToughMix Kit }\end{array}$ & $\begin{array}{c}\text { Luna }^{\circledR} \text { Universal } \\
\text { Probe One-Step } \\
\text { RT-qPCR Kit }\end{array}$ \\
\hline reverse transcription & $55^{\circ} \mathrm{C}$ for $20 \mathrm{~min}$ & $45^{\circ} \mathrm{C}$ for $10 \mathrm{~min}$ & $50^{\circ} \mathrm{C}$ for $10 \mathrm{~min}$ & $55^{\circ} \mathrm{C}$ for $10 \mathrm{~min}$ \\
\hline $\begin{array}{l}\text { PCR initial activation } \\
\text { three step cycling } \\
\text { ( } 42 \text { cycles): }\end{array}$ & $95^{\circ} \mathrm{C}$ for $3 \mathrm{~min}$ & $95^{\circ} \mathrm{C}$ for $10 \mathrm{~min}$ & $95^{\circ} \mathrm{C}$ for $1 \mathrm{~min}$ & $95^{\circ} \mathrm{C}$ for $1 \mathrm{~min}$ \\
\hline denaturation & \multirow{3}{*}{$\begin{array}{l}95^{\circ} \mathrm{C} \text { for } 15 \mathrm{~s} \\
58^{\circ} \mathrm{C} \text { for } 30 \mathrm{~s} \\
\text { (combined with } \\
\text { annealing) }\end{array}$} & $95^{\circ} \mathrm{C}$ for $15 \mathrm{~s}$ & $95^{\circ} \mathrm{C}$ for $15 \mathrm{~s}$ & $95^{\circ} \mathrm{C}$ for $10 \mathrm{~s}$ \\
\hline annealing & & $57^{\circ} \mathrm{C}$ for $20 \mathrm{~s}$ & $57^{\circ} \mathrm{C}$ for $20 \mathrm{~s}$ & $57^{\circ} \mathrm{C}$ for $20 \mathrm{~s}$ \\
\hline extension & & $72{ }^{\circ} \mathrm{C}$ for $20 \mathrm{~s}$ & $68^{\circ} \mathrm{C}$ for $30 \mathrm{~s}$ & $68^{\circ} \mathrm{C}$ for $30 \mathrm{~s}$ \\
\hline
\end{tabular}

All the following tests were performed in a reduced total reaction volume and in comparison to the assay IP4.

As a next step, a dilution series of RNA extracted from a whole virus preparation was tested by each of the three SARS-CoV-2 PCRs, i.e., IP4, E-Sarbeco and CDC-N3, in combination with the AgPath-ID One-Step RT-PCR Reagents kit (Thermo Fisher Scientific) or the qScript XLT One-Step RT-qPCR ToughMix kit (Quantabio, Beverly, MA, USA). To further increase the flexibility of the real-time RT-PCR setup, a third PCR kit was included, namely the Luna ${ }^{\circledR}$ Universal Probe One-Step RT-qPCR kit (New England Biolabs GmbH, Frankfurt am Main, Germany; $198 €$ per 200 reactions). For a single reaction, $4.5 \mu \mathrm{L}$ RNasefree water, $5 \mu \mathrm{L} 2 \times$ Luna Universal Probe One-Step Reaction Mix, $0.5 \mu \mathrm{L} 20 \times$ Luna WarmStart ${ }^{\circledR}$ RT Enzyme Mix, and $2.5 \mu \mathrm{L}$ RNA template were merged. For amplification, the reaction was carried out at the temperature profile given in Table 1.

Finally, the SARS-CoV-2 real-time RT-PCR assays were combined with an IC system based on the housekeeping gene beta-actin [22] or with a heterologous IC [19] to control for efficient RNA extraction and amplification, thereby preventing false-negative results. The duplex PCRs were exemplarily tested in combination with the AgPath-ID One-Step RT-PCR Reagents kit (Thermo Fisher Scientific) in a total reaction volume of $12.5 \mu \mathrm{L}$.

In order to evaluate the diagnostic sensitivity and specificity of the modified real-time RT-PCRs, the clinical swab samples were investigated by each of the three SARS-CoV-2 RTPCRs in combination with the ICs and either the AgPath-ID One-Step RT-PCR Reagents kit (Thermo Fisher Scientific) or the qScript XLT One-Step RT-qPCR ToughMix kit (Quantabio). The diagnostic sensitivity, specificity, and accuracy were calculated by using the free statistical calculator MedCalc (MedCalc Software, Ostend, Belgium).

All oligonucleotides were synthesized by either metabion international AG (Planegg, Germany) or TIBMOLBIOL (Berlin, Germany) and the real-time RT-PCR reactions were carried out using a Bio-Rad CFX 96 Real-Time Detection System (Bio-Rad, Hercules, CA, USA). 


\section{Results}

3.1. Volume Reduction of Reagents to $12.5 \mu \mathrm{L}$ and Type of Used PCR Chemistry Did Not Influence the PCR Sensitivity

A dilution series of the RNA standard was tested by the IP4 real-time RT-PCR combined with different volumes of the AgPath-ID One-Step RT-PCR Reagents and qScript XLT One-Step RT-qPCR ToughMix kits in comparison to the published protocol [13]. From $10^{3}$ to $10^{1}$ copies $/ \mu \mathrm{L}$, every replicate of each approach tested positive, and comparable quantification cycle $(\mathrm{Cq})$ values were obtained (Figure 1). The LOD95\% was below 10 for every approach (Supplementary Table S1). For SARS-CoV-2 dilutions containing $2 \times 10^{0}$ or $1 \times 10^{0}$ copies $/ \mu \mathrm{L}$, some of the replicates scored negative. However, an influence of a specific PCR kit or total reaction volume could not be observed, as none of the approaches failed to detect every replicate of a given RNA concentration, and even these very low concentrations could be detected by RT-PCR set-ups using reduced volumes (Figure 1). Hence, all the following analyses were carried out using a total reaction volume of $12.5 \mu \mathrm{L}$.

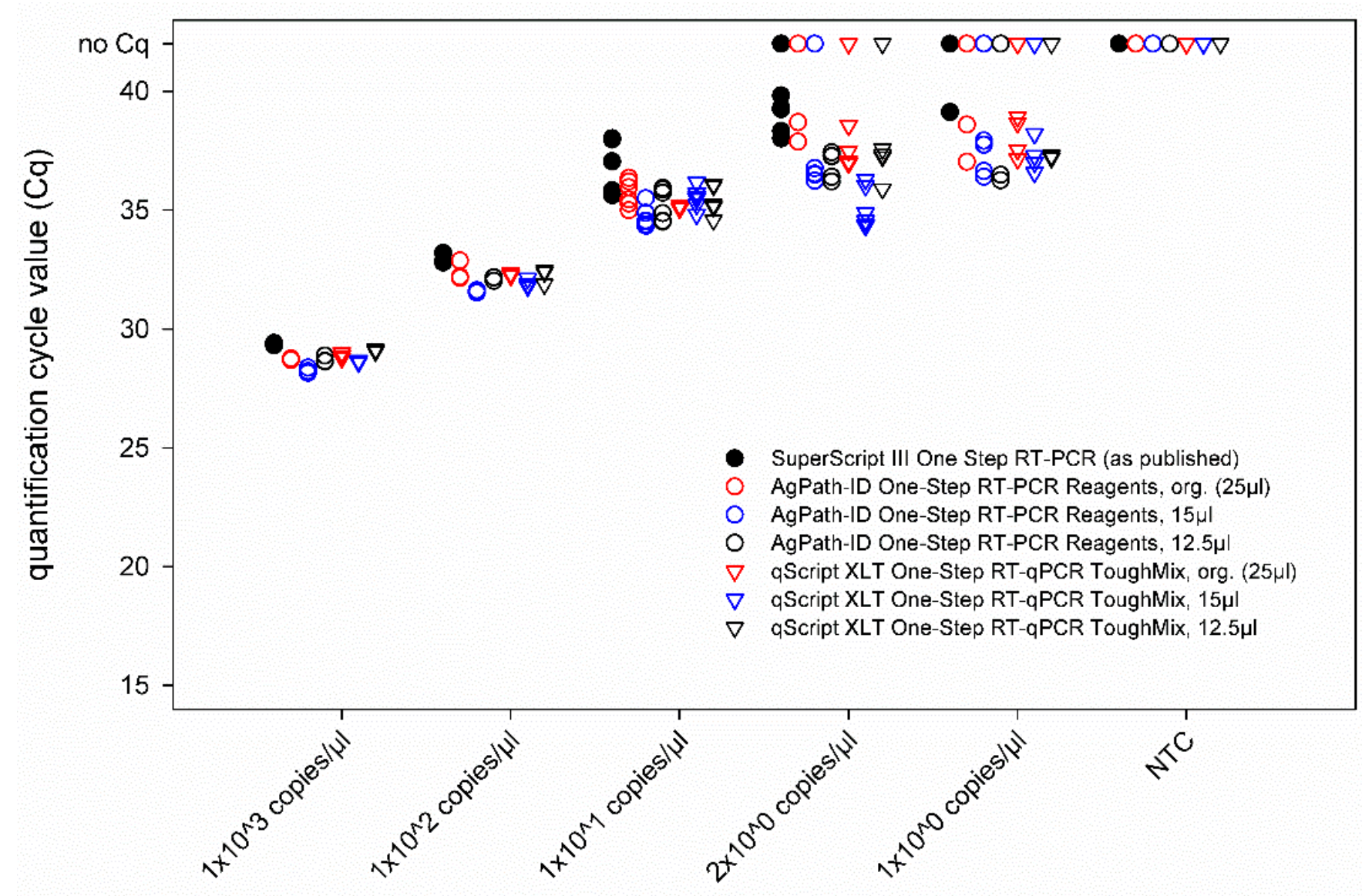

concentration of SARS-CoV-2 RNA

Figure 1. Comparison of the IP4 real-time RT-PCR performed with different real-time RT-PCR kits and total reaction volumes. The newly established protocols were compared to the previously published version of this PCR using SARS-CoV-2 standard RNA. Org.- - original protocol described by the manufacturers of the RT-PCR kits. NTC—no template control (=RNase free water).

Next, a ten-fold dilution series of culture-grown virus was tested. This virus preparation contained $8.21 \times 10^{6}$ RNA copies per $\mu \mathrm{L}$ RNA template, as was determined based on an external standard. When comparing the three different SARS-CoV-2 real-time RT-PCRs, i.e., IP4, E-Sarbeco, and CDC-N3, run in combination with either the AgPath-ID One-Step RT-PCR Reagents kit, the qScript XLT One-Step RT-qPCR ToughMix kit, or the Luna ${ }^{\circledR}$ 
Universal Probe One-Step RT-qPCR kit, nearly identical Cq values were obtained in every approach (Figure 2). Only in the highest virus dilution was a certain degree of variability observed, but without a prominent effect of a given real-time PCR chemistry, since in every combination, at least one of the duplicates tested weakly positive (Figure 2).

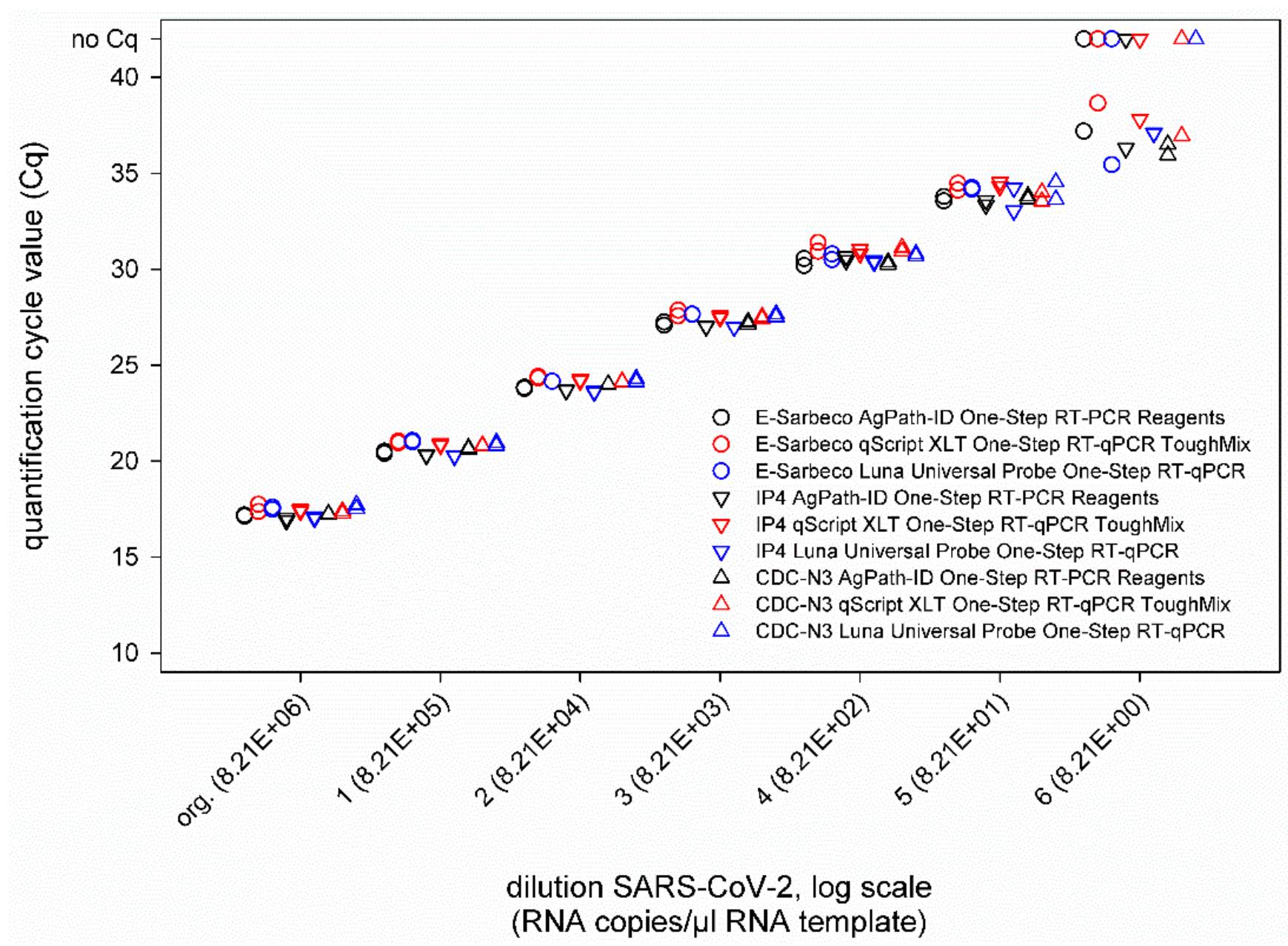

Figure 2. Results of the SARS-CoV-2 real-time RT-PCRs E-Sarbeco, IP4 and CDC-N3 performed in combination with either the AgPath-ID One-Step RT-PCR Reagents kit (black), the qScript XLT One-Step RT-qPCR kit (red), or the Luna Universal Probe One-Step RT-qPCR kit (blue). All samples were tested in duplicate.

In addition, the combination of the SARS-CoV-2 real-time RT-PCRs with IC systems did not negatively influence the PCR performance (Figure 2), as nearly identical Cq values were measured for SARS-CoV-2 dilutions (second virus preparation) ranging from $10^{-2}$ to $10^{-7}$ (corresponding to $9.21 \times 10^{5}$ to $9.21 \times 10^{0}$ RNA copies per $\mu$ LNA template) in singleplex and duplex approaches, independent of the applied IC assay (Figure 3 ). The LOD95\% of every approach is given in Supplementary Table S2. 


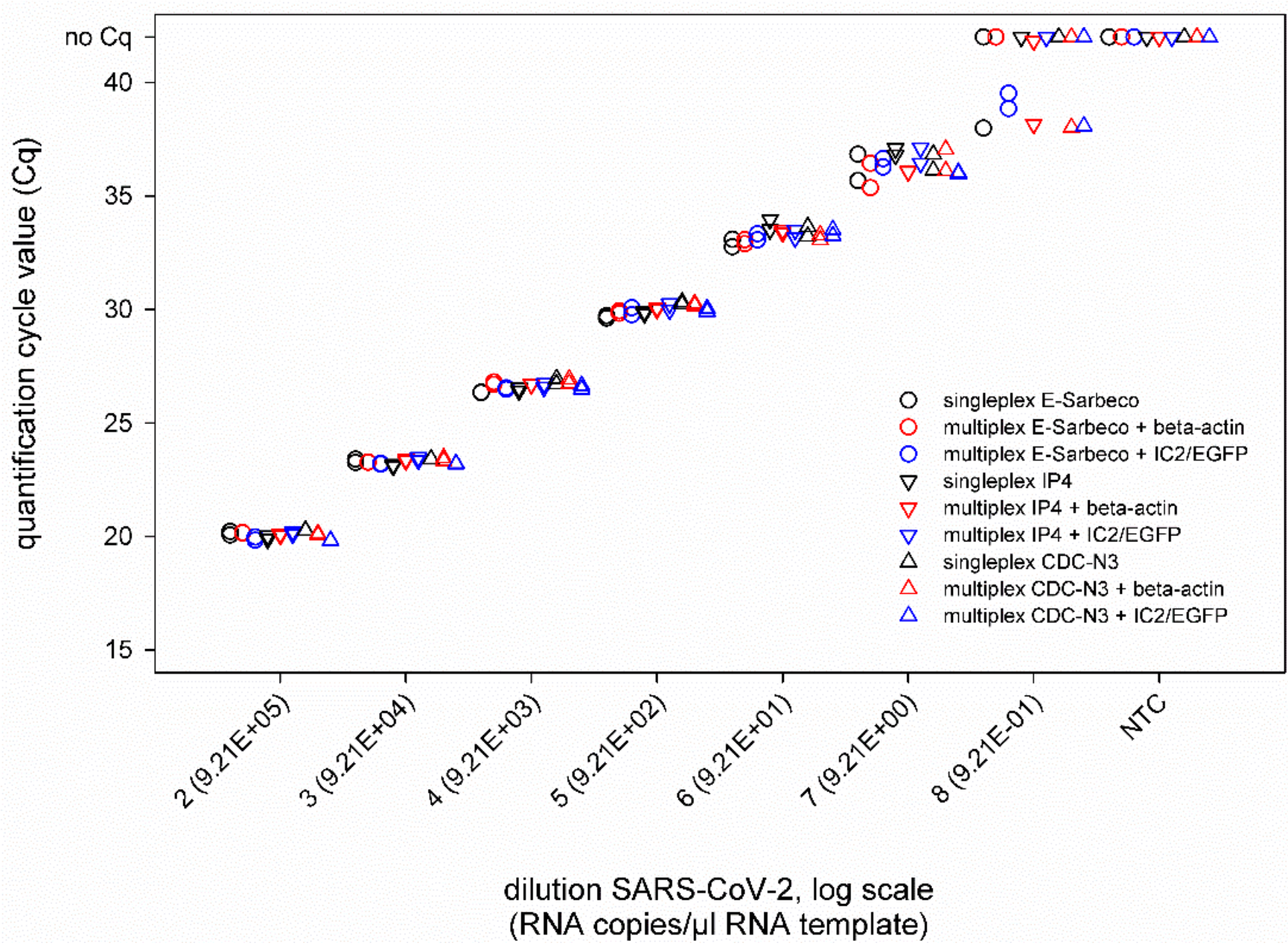

Figure 3. Results of the SARS-CoV-2 real-time RT-PCRs E-Sarbeco, IP4 and CDC-N3 performed either individually (black) or in a duplex reaction with an internal control assay based on the housekeeping gene beta-actin (red) or a heterologous control (IC2/EGFP, blue). All samples were tested in duplicate. NTC—no template control (=RNase free water).

\subsection{Diagnostic Performance of the Optimized Real-Time PCR Protocols with Clinical Samples}

The performance of all duplex real-time RT-PCRs was also investigated using human pharyngeal swabs with two different PCR kits. While the IC systems tested correctly positive in every approach where the duplex PCRs were combined with the AgPath-ID One-Step RT-PCR Reagent kit, the beta-actin based IC scored negative for five or three of the 73 negative swab samples, respectively, when the E-Sarbeco and CDC-N3 PCRs were combined with the qScript XLT One-Step RT-qPCR kit (Table 2). Regarding the SARS-CoV-2 real-time RT-PCRs, agreeing results were obtained for all RT-PCR/chemistry-combinations for virus negative clinical specimens and swabs containing high to medium viral genome loads. In cases of very low SARS-CoV-2 genome loads $(\mathrm{Cq}>36)$, inconsistent results were observed, with some approaches scoring negative and some positive. However, no preference of a specific target within the viral genome $(\mathrm{E}, \mathrm{RdRp}$ or $\mathrm{N})$ or of a certain PCR chemistry could be observed (Table 2). 


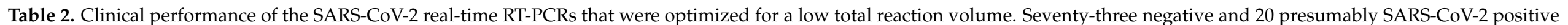

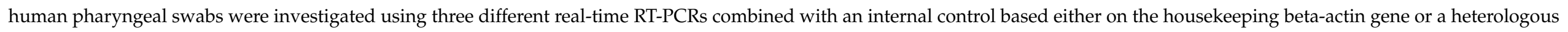

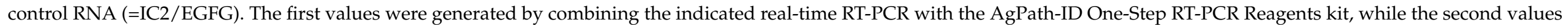

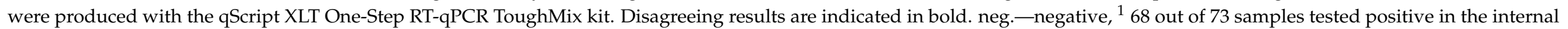
control assay, ${ }^{2} 70$ out of 73 samples tested positive in the internal control assay.

\begin{tabular}{|c|c|c|c|c|c|c|c|c|c|c|c|c|}
\hline \multirow{2}{*}{$\begin{array}{c}\text { Sample } \\
\text { Material }\end{array}$} & \multicolumn{4}{|c|}{ E-Sarbeco } & \multicolumn{4}{|c|}{ IP4 } & \multicolumn{4}{|c|}{ CDC-N3 } \\
\hline & SARS-CoV-2 & Beta-Actin & $\begin{array}{c}\text { SARS-CoV- } \\
2\end{array}$ & IC2/EGFP & $\begin{array}{c}\text { SARS-CoV- } \\
2\end{array}$ & Beta-Actin & $\begin{array}{c}\text { SARS-CoV- } \\
2\end{array}$ & IC2/EGFP & $\begin{array}{l}\text { SARS- } \\
\text { CoV-2 }\end{array}$ & $\begin{array}{l}\text { Beta- } \\
\text { Actin }\end{array}$ & $\begin{array}{l}\text { SARS- } \\
\text { CoV-2 }\end{array}$ & IC2/EGFP \\
\hline $\begin{array}{c}\text { human } \\
\text { pharyngeal } \\
\text { swab }(\mathrm{n}=73) \\
\text { human }\end{array}$ & neg. & $\begin{array}{l}28.8 \pm 3.0 / \\
31.3 \pm 4.9^{1}\end{array}$ & neg. & $\begin{array}{c}23.9 \pm 0.1 / \\
24.6 \pm 0.2\end{array}$ & neg. & $\begin{array}{c}29.7 \pm 3.1 / \\
30.5 \pm 2.8\end{array}$ & neg. & $\begin{array}{c}24.4 \pm 0.2 / \\
24.8 \pm 0.1\end{array}$ & neg. & $\begin{array}{c}28.5 \pm \\
3.1 / 29.9 \\
\pm 3.4^{2}\end{array}$ & neg. & $\begin{array}{c}24.6 \pm \\
0.2 / 23.8 \\
\pm 0.2\end{array}$ \\
\hline $\begin{array}{c}\text { pharyngeal } \\
\text { swab \#74 } \\
\text { human }\end{array}$ & $23.6 / 23.8$ & $28.3 / 29.4$ & $24.3 / 24.0$ & $25.6 / 26.2$ & $23.9 / 24.1$ & $28.9 / 31.4$ & $24.4 / 24.2$ & $26.0 / 27.1$ & $24.4 / 23.5$ & $28.1 / 29.4$ & $24.2 / 23.5$ & $25.3 / 24.3$ \\
\hline $\begin{array}{l}\text { pharyngeal } \\
\text { swab \#75 } \\
\text { human }\end{array}$ & $33.9 / 34.4$ & $29.4 / 30.8$ & $35.6 / 34.5$ & $25.7 / 25.9$ & $35.0 / 36.0$ & $29.6 / 31.5$ & $34.0 / 33.8$ & $25.7 / 26.7$ & $35.7 / 33.1$ & $29.2 / 30.1$ & $34.9 / 33.5$ & $25.1 / 24.1$ \\
\hline $\begin{array}{l}\text { pharyngeal } \\
\text { swab \#76 } \\
\text { human }\end{array}$ & $27.5 / 28.1$ & $27.2 / 28.9$ & $28.4 / 28.1$ & $25.7 / 26.1$ & $27.8 / 28.0$ & $27.5 / 29.5$ & $28.2 / 28.0$ & $25.5 / 26.6$ & $28.5 / 27.3$ & $27.1 / 28.2$ & $28.4 / 27.6$ & $24.8 / 24.1$ \\
\hline $\begin{array}{c}\text { pharyngeal } \\
\text { swab \#77 } \\
\text { human }\end{array}$ & $25.1 / 25.1$ & $34.4 / 36.9$ & $25.4 / 25.2$ & $25.7 / 26.2$ & $24.7 / 24.2$ & $34.1 / 36.0$ & $25.0 / 25.1$ & $25.7 / 27.0$ & $25.3 / 24.2$ & 35.2/neg. & $25.1 / 24.4$ & $24.8 / 24.1$ \\
\hline $\begin{array}{l}\text { pharyngeal } \\
\text { swab \#78 } \\
\text { human }\end{array}$ & $24.2 / 24.0$ & $29.0 / 30.4$ & $25.0 / 24.3$ & $25.7 / 26.2$ & $24.1 / 24.1$ & 29.6/31.4 & $24.3 / 24.2$ & $25.5 / 26.7$ & $24.8 / 23.8$ & $28.2 / 29.8$ & $24.5 / 24.0$ & $24.8 / 24.1$ \\
\hline $\begin{array}{l}\text { pharyngeal } \\
\text { swab \#79 } \\
\text { human }\end{array}$ & neg./neg. & $32.5 / 34.1$ & neg./37.1 & $25.7 / 26.1$ & neg./neg. & $32.5 / 35.1$ & neg./neg. & $25.5 / 26.5$ & neg./neg. & $31.5 / 35.4$ & neg./neg. & $24.8 / 24.1$ \\
\hline $\begin{array}{c}\text { pharyngeal } \\
\text { swab \#80 }\end{array}$ & neg./37.3 & $32.0 / 34.4$ & neg./neg. & $25.4 / 26.2$ & neg./neg. & $32.6 / 34.9$ & neg./37.4 & $25.4 / 26.5$ & 36.6/neg. & $32.2 / 34.4$ & neg./neg. & $25.0 / 23.9$ \\
\hline
\end{tabular}


Table 2. Cont.

\begin{tabular}{|c|c|c|c|c|c|c|c|c|c|c|c|c|}
\hline \multirow{2}{*}{$\begin{array}{c}\text { Sample } \\
\text { Material }\end{array}$} & \multicolumn{4}{|c|}{ E-Sarbeco } & \multicolumn{4}{|c|}{ IP4 } & \multicolumn{4}{|c|}{ CDC-N3 } \\
\hline & SARS-CoV-2 & Beta-Actin & $\begin{array}{c}\text { SARS-CoV- } \\
2\end{array}$ & IC2/EGFP & $\begin{array}{c}\text { SARS-CoV- } \\
2\end{array}$ & Beta-Actin & $\begin{array}{c}\text { SARS-CoV- } \\
2\end{array}$ & IC2/EGFP & $\begin{array}{l}\text { SARS- } \\
\text { CoV-2 }\end{array}$ & $\begin{array}{l}\text { Beta- } \\
\text { Actin }\end{array}$ & $\begin{array}{l}\text { SARS- } \\
\text { CoV-2 }\end{array}$ & IC2/EGFP \\
\hline $\begin{array}{c}\text { human } \\
\text { pharyngeal } \\
\text { swab \#81 }\end{array}$ & $26.2 / 26.1$ & $30.4 / 31.8$ & $26.8 / 26.3$ & $25.6 / 26.1$ & $26.3 / 26.2$ & $31.2 / 32.8$ & $26.3 / 26.3$ & $25.3 / 26.6$ & $26.7 / 25.6$ & $30.1 / 31.8$ & $26.4 / 25.5$ & $24.8 / 23.7$ \\
\hline $\begin{array}{c}\text { human } \\
\text { pharyngeal } \\
\text { swab \#82 } \\
\text { human }\end{array}$ & $28.2 / 28.7$ & $33.4 / 35.6$ & $28.2 / 28.8$ & $25.3 / 26.1$ & $28.9 / 28.9$ & $34.4 / 35.6$ & $28.6 / 28.8$ & $25.5 / 26.6$ & $28.5 / 27.6$ & 33.3/neg. & $28.3 / 27.2$ & $25.3 / 24.1$ \\
\hline $\begin{array}{c}\text { pharyngeal } \\
\text { swab \#83 } \\
\text { human }\end{array}$ & $29.4 / 29.4$ & $31.3 / 33.1$ & $29.9 / 29.6$ & $25.8 / 26.3$ & $29.3 / 29.5$ & $31.7 / 33.7$ & $29.4 / 29.4$ & $26.0 / 26.9$ & $30.2 / 28.6$ & $30.9 / 32.8$ & $29.5 / 28.5$ & $25.2 / 24.1$ \\
\hline $\begin{array}{c}\text { pharyngeal } \\
\text { swab \#84 } \\
\text { human }\end{array}$ & neg./36.2 & $32.9 / 35.3$ & neg./neg. & $25.8 / 26.2$ & $37.0 / 37.2$ & $33.7 / 35.5$ & neg./neg. & $25.9 / 26.5$ & neg./neg. & 33.8/neg. & 36.59/neg. & $24.8 / 24.0$ \\
\hline $\begin{array}{c}\text { pharyngeal } \\
\text { swab \#85 } \\
\text { human }\end{array}$ & $31.5 / 31.1$ & $31.7 / 34.4$ & $31.8 / 31.9$ & $25.8 / 26.1$ & $31.4 / 31.5$ & $32.5 / 34.3$ & $31.4 / 31.5$ & $25.6 / 26.7$ & $31.8 / 30.7$ & $31.5 / 33.0$ & $31.4 / 30.4$ & $24.8 / 24.1$ \\
\hline $\begin{array}{c}\text { pharyngeal } \\
\text { swab \#86 } \\
\text { human }\end{array}$ & $31.7 / 31.7$ & $30.1 / 31.2$ & $32.0 / 31.6$ & $25.7 / 26.2$ & $31.7 / 21.1$ & $29.9 / 31.7$ & $31.3 / 31.7$ & $25.6 / 26.8$ & $31.5 / 30.2$ & $29.3 / 30.5$ & $31.7 / 30.4$ & $24.9 / 24.1$ \\
\hline $\begin{array}{c}\text { pharyngeal } \\
\text { swab \#87 } \\
\text { human }\end{array}$ & $36.8 / 36.1$ & $32.7 / 34.6$ & $34.7 / 35.5$ & $25.6 / 26.0$ & $35.0 / 35.1$ & $33.4 / 35.1$ & $35.7 / 35.0$ & $25.6 / 26.3$ & $38.1 / 35.8$ & $32.6 / 34.5$ & 35.0/neg. & $24.8 / 23.8$ \\
\hline $\begin{array}{c}\text { pharyngeal } \\
\text { swab \#88 } \\
\text { human }\end{array}$ & $29.3 / 29.3$ & $30.3 / 31.7$ & $29.6 / 29.6$ & $25.5 / 25.9$ & $29.4 / 29.3$ & $31.0 / 32.9$ & $29.4 / 29.3$ & $25.5 / 26.5$ & $30.1 / 28.3$ & $30.2 / 31.3$ & $29.8 / 28.3$ & $24.8 / 23.7$ \\
\hline $\begin{array}{c}\text { pharyngeal } \\
\text { swab \#89 } \\
\text { human }\end{array}$ & $30.1 / 31.1$ & $34.2 / 38.8$ & $31.3 / 31.1$ & $25.6 / 26.3$ & $31.7 / 31.3$ & $34.1 / 36.4$ & $30.8 / 31.1$ & $25.1 / 26.6$ & $31.2 / 30.1$ & 33.8/neg. & $30.7 / 29.5$ & $24.8 / 23.8$ \\
\hline $\begin{array}{c}\text { pharyngeal } \\
\text { swab \#90 }\end{array}$ & $26.0 / 26.2$ & $28.8 / 30.0$ & $26.4 / 26.2$ & $25.7 / 26.0$ & $26.1 / 26.2$ & $29.2 / 31.3$ & $26.2 / 26.4$ & $25.6 / 26.6$ & $26.6 / 25.6$ & $28.6 / 27.8$ & $26.5 / 25.6$ & $25.0 / 24.2$ \\
\hline
\end{tabular}


Table 2. Cont

\begin{tabular}{|c|c|c|c|c|c|c|c|c|c|c|c|c|}
\hline \multirow[t]{2}{*}{$\begin{array}{l}\text { Sample } \\
\text { Material }\end{array}$} & \multicolumn{4}{|c|}{ E-Sarbeco } & \multicolumn{4}{|c|}{ IP4 } & \multicolumn{4}{|c|}{ CDC-N3 } \\
\hline & SARS-CoV-2 & Beta-Actin & $\begin{array}{c}\text { SARS-CoV- } \\
2\end{array}$ & IC2/EGFP & $\begin{array}{c}\text { SARS-CoV- } \\
2\end{array}$ & Beta-Actin & $\begin{array}{c}\text { SARS-CoV- } \\
2\end{array}$ & IC2/EGFP & $\begin{array}{l}\text { SARS- } \\
\text { CoV-2 }\end{array}$ & $\begin{array}{l}\text { Beta- } \\
\text { Actin }\end{array}$ & $\begin{array}{l}\text { SARS- } \\
\text { CoV-2 }\end{array}$ & IC2/EGFP \\
\hline $\begin{array}{l}\text { human } \\
\text { pharyngeal } \\
\text { swab \#91 } \\
\text { human }\end{array}$ & $30.1 / 30.3$ & $28.0 / 29.3$ & $30.5 / 30.1$ & $26.0 / 26.2$ & $30.2 / 30.3$ & $28.0 / 30.1$ & $30.1 / 30.1$ & $25.6 / 26.8$ & $30.0 / 28.7$ & $27.3 / 28.4$ & $29.7 / 28.5$ & $24.8 / 24.2$ \\
\hline $\begin{array}{l}\text { pharyngeal } \\
\text { swab \#92 } \\
\text { human }\end{array}$ & $36.3 / 36.0$ & $28.2 / 30.0$ & neg./36.6 & $25.9 / 26.0$ & $36.8 / 38.0$ & $28.4 / 30.3$ & neg./36.1 & $25.4 / 26.5$ & $37.8 / 41.3$ & $27.7 / 28.9$ & neg./36.1 & $24.7 / 24.0$ \\
\hline $\begin{array}{l}\text { pharyngeal } \\
\text { swab \#93 }\end{array}$ & $27.5 / 27.4$ & $32.1 / 34.1$ & $27.9 / 27.5$ & $25.7 / 26.1$ & $27.2 / 27.3$ & $32.9 / 34.8$ & $27.3 / 27.3$ & $25.4 / 26.5$ & $28.0 / 27.0$ & $32.0 / 34.6$ & $27.5 / 27.0$ & $24.9 / 24.0$ \\
\hline $\begin{array}{l}\text { diagnostic } \\
\text { specificity }\end{array}$ & $\begin{array}{l}100.00 \% / \\
100.00 \%\end{array}$ & & $\begin{array}{l}100.00 \% / \\
100.00 \%\end{array}$ & & $\begin{array}{l}100.00 \% / \\
100.00 \%\end{array}$ & & $\begin{array}{l}100.00 \% / \\
100.00 \%\end{array}$ & & $\begin{array}{l}100.00 \% / \\
100.00 \%\end{array}$ & & $\begin{array}{c}100.00 \% / \\
100.00 \%\end{array}$ & \\
\hline diagnostic & $85.00 \% /$ & & $80.00 \% /$ & & $90.00 \% /$ & & $80.00 \% /$ & & $90.00 \% /$ & & $80.00 \%$ / & \\
\hline sensitivity & $95.00 \%$ & & $90.00 \%$ & & $90.00 \%$ & & $90.00 \%$ & & $90.00 \%$ & & $95.00 \%$ & \\
\hline accuracy & $\begin{array}{l}96.77 \% / \\
98.92 \%\end{array}$ & & $\begin{array}{c}95.70 \% / \\
97.85 \%\end{array}$ & & $\begin{array}{l}97.85 \% / \\
97.85 \%\end{array}$ & & $\begin{array}{c}95.70 \% / \\
97.85\end{array}$ & & $\begin{array}{l}97.85 \% / \\
97.85 \%\end{array}$ & & $\begin{array}{l}95.70 \% / \\
98.92 \%\end{array}$ & \\
\hline
\end{tabular}




\section{Discussion}

Since SARS-CoV-2 became a pandemic in early 2020, this virus is keeping the world in suspense as the control measures affect all areas of life, and the disease itself heavily challenges health care systems and diagnostic capacities. To identify and isolate infected persons, inconceivably large numbers of RT-PCR tests need to be performed $[2,9,10]$. In comparison to spring and summer (the so-called "first wave"), the number of tests even increased in the northern hemisphere's autumn 2020 and winter 2020/21, when many countries have faced a "second wave", i.e., strongly increasing case numbers $[23,24]$. Furthermore, since mid-2021, multiple countries are experiencing a massive wave of infections driven by the Delta variant or other variants of concerns [25]. In times of growing demand for testing, the availability of test kits may be a problematic issue. To overcome supply shortages of individual reagents, a reduction of the required reaction volume, pooling of samples, or falling back on alternative reagents might be problemsolving approaches. The concept of volume reduction of the applied PCR chemistry has been already proposed and successfully implemented recently for diagnostics of influenza A viruses in low- and middle-income countries [26]. Here, it could be demonstrated that a significant reduction of PCR reagents to $12.5 \mu \mathrm{L}$ /well without negatively influencing the sensitivity of SARS-CoV-2 RT-PCR assays is likewise possible. In addition, an adequate robustness of the applied RT-PCR protocols was observed, even when diverse master mixes were used, further increasing the flexibility in times of overwhelming need for SARS-CoV-2 PCR diagnostics. However, when new assay/chemistry combinations not included in this comparison are to be used, they should be validated in comparison to well-established systems, since the PCR chemistry could negatively influence the performance of the test. This was e.g., shown in the present study for the IC that failed to react correctly positive in very few cases when two of the duplex PCR systems were combined with the qScript XLT One-Step RT-qPCR kit.

An additional option to save resources when dealing with large amounts of sample specimens is pooling approaches, since they could drastically increase the sample throughput. In veterinary medicine, this experience was made with a variety of pathogens, among them numerous viruses and diverse sample materials already years ago [26-29], and only recently, several groups confirmed the applicability of sample pooling for SARS-CoV-2 diagnostic as well [30-34]. However, pooling is only a useful option in situations of a low virus prevalence, e.g., in screening asymptomatic populations in regions with only low-level virus circulation, as every positive pool needs to be resolved to test each included sample individually. When pooling of samples is further combined with reduced PCR volumes, which can be ideally used flexibly with different PCR master mixes, the diagnostic capacity could be drastically increased. Such approaches are in particular beneficial when health care workers can be regularly screened for infection even in resource-limited settings, thereby avoiding the transmission of SARS-CoV-2 into care homes of the elderly, which are most at risk of severe disease and death when the residents are not yet vaccinated [35,36].

Within the different duplex RT-PCR protocols established in the present study, the tested SARS-CoV-2 assays proved to be equally sensitive as the corresponding single-target RTPCRs, which excludes a negative effect of the IC amplification, while the inclusion of ICs markedly increases the diagnostic certainty. However, in cases of very low SARS-CoV-2 genome loads, inconsistent results were observed in the virus-specific RT-PCRs. Such low viral RNA loads, which are near the limit of detection of the diagnostic systems, can be found in the upper respiratory tract in later phases after infection [37-39] and most likely do not equate to infectiousness [40,41]. In a previous study on COVID-19 patients, it was shown that the probability of isolating infectious virus was less than $5 \%$ when the viral RNA load was below $6.63 \log 10 \mathrm{RNA}$ copies/mL [42]. This is strikingly similar to the cut off of $6.51 \log 10$ RNA copies/mL reported in another study [39]. These observations and values implicate that patients below this value are not infectious anymore. 
Nevertheless, the re-testing of the person concerned is highly recommended, to exclude, e.g., suboptimal sampling.

\section{Conclusions}

In the current comparative study, neither a marked reduction of the total reaction volume nor the type of RT-PCR chemistry negatively influenced the sensitivity of the applied real-time RT-PCR assays, as shown by equivalent results when testing dilution series of SARS-CoV-2 standard RNA or RNA extracted from culture-grown virus. However, when other RT-PCR kits that were not included in this study are to be used for SARS-CoV-2 diagnostics, an initial validation of the new kit and of the reaction conditions (e.g., volume, thermal profile) is highly recommended. For this, one should compare the intended protocol to a well-validated system, preferably the originally published protocol.

Since inconsistent results were observed in cases of very low SARS-CoV-2 genome loads ( $\mathrm{Cq}>36,<100$ genome copies) in this study, two independent RT-PCR assays should be applied in all cases, ideally targeting different genomic regions, for the reliable diagnostics of SARS-CoV-2 infections by real-time RT-PCR even in patients with very low genome loads at the time of sampling.

Supplementary Materials: The following are available online at https:/ /www.mdpi.com/article/10 .3390 / diseases $9040084 / \mathrm{s} 1$, Table S1: Limit of detection LOD95\% of the protocols used in this study as determined based on a PCR standard provided by Charité-Universitätsmedizin Berlin, Germany, via European Virus Archive goes global (EVAg), Ref-SKU: 026N-03889. Org.- original protocol. Table S2: Limit of detection LOD95\% of the protocols used in this study as determined based on two distinct preparations of culture-grown SARS-CoV-2.

Author Contributions: Conceptualization, S.B., B.H., M.B. and K.W.; methodology, S.B., B.H. and K.W.; validation, S.B., B.H. and K.W.; formal analysis, S.B., B.H. and K.W.; investigation, S.B., B.H. and K.W.; writing—original draft preparation, K.W.; writing—review and editing, S.B., B.H. and M.B.; visualization, K.W. All authors have read and agreed to the published version of the manuscript.

Funding: This research received no external funding.

Institutional Review Board Statement: Ethical review and approval were waived for this study, since all activities are according to legal provisions defined by the German Infection Protection Act (IfSG). All samples have been submitted for routine diagnostics.

Informed Consent Statement: Patient consent was waived, since all activities are according to legal provisions defined by the German Infection Protection Act (IfSG). All samples have been submitted for routine diagnostics.

Data Availability Statement: The data presented in this study are available in the article.

Acknowledgments: We thank Cornelia Andres, Christian Korthase and Bianka Hillmann for excellent technical assistance.

Conflicts of Interest: The authors declare no conflict of interest.

\section{References}

1. WHO. Pneumonia of Unknown Cause-China. 2020. Available online: https://www.who.int/csr/don/05-january-2020 -pneumonia-of-unkown-cause-china (accessed on 16 May 2020).

2. WHO. Covid-19 Strategy Update-14 April 2020. Available online: https://www.who.int/publications-detail/covid-19-strategyupdate---14-april-2020 (accessed on 16 May 2020).

3. Dong, E.; Du, H.; Gardner, L. An interactive web-based dashboard to track covid-19 in real time. Lancet Infect. Dis. 2020, 20, 533-534. [CrossRef]

4. Zhu, N.; Zhang, D.; Wang, W.; Li, X.; Yang, B.; Song, J.; Zhao, X.; Huang, B.; Shi, W.; Lu, R.; et al. A novel coronavirus from patients with pneumonia in China, 2019. N. Engl. J. Med. 2020, 382, 727-733. [CrossRef] [PubMed]

5. He, X.; Lau, E.H.Y.; Wu, P.; Deng, X.; Wang, J.; Hao, X.; Lau, Y.C.; Wong, J.Y.; Guan, Y.; Tan, X.; et al. Temporal dynamics in viral shedding and transmissibility of covid-19. Nat. Med. 2020, 26, 672-675. [CrossRef] [PubMed]

6. Kaur, S.; Bherwani, H.; Gulia, S.; Vijay, R.; Kumar, R. Understanding covid-19 transmission, health impacts and mitigation: Timely social distancing is the key. Environ. Dev. Sustain. 2020, 23, 6681-6697. [CrossRef] [PubMed] 
7. Islam, N.; Sharp, S.J.; Chowell, G.; Shabnam, S.; Kawachi, I.; Lacey, B.; Massaro, J.M.; D'Agostino, R.B., Sr.; White, M. Physical distancing interventions and incidence of coronavirus disease 2019: Natural experiment in 149 countries. BMJ 2020, $370, \mathrm{~m} 2743$. [CrossRef]

8. Li, Y.; Campbell, H.; Kulkarni, D.; Harpur, A.; Nundy, M.; Wang, X.; Nair, H. The temporal association of introducing and lifting non-pharmaceutical interventions with the time-varying reproduction number (r) of Sars-CoV-2: A modelling study across 131 countries. Lancet Infect. Dis. 2020, 21, 193-202. [CrossRef]

9. Hasell, J.; Ortiz-Ospina, E.; Mathieu, E.; Ritchie, H.; Beltekian, D.; Macdonald, B.; Roser, M. Coronavirus (Covid-19) Testing. Our World in Data. 2020. Available online: https:/ / ourworldindata.org/coronavirus-testing (accessed on 16 May 2020).

10. Lorusso, A.; Calistri, P.; Mercante, M.T.; Monaco, F.; Portanti, O.; Marcacci, M.; Camma, C.; Rinaldi, A.; Mangone, I.; Di Pasquale, A.; et al. A "one-health" approach for diagnosis and molecular characterization of Sars-CoV-2 in Italy. One Health 2020, 10, 100135. [CrossRef]

11. Bulterys, P.L.; Garamani, N.; Stevens, B.; Sahoo, M.K.; Huang, C.; Hogan, C.A.; Zehnder, J.; Pinsky, B.A. Comparison of a laboratory-developed test targeting the envelope gene with three nucleic acid amplification tests for detection of Sars-CoV-2 J. Clin. Virol. 2020, 129, 104427. [CrossRef]

12. Park, M.; Won, J.; Choi, B.Y.; Lee, C.J. Optimization of primer sets and detection protocols for Sars-CoV-2 of coronavirus disease 2019 (Covid-19) using PCR and real-time PCR. Exp. Mol. Med. 2020, 52, 963-977. [CrossRef]

13. WHO. Coronavirus Disease (Covid-19) Technical Guidance: Laboratory Testing for 2019-ncov in Humans. 2020. Available online: https:/ / www.who.int/emergencies/diseases/novel-coronavirus-2019/technical-guidance/laboratory-guidance (accessed on 16 May 2020).

14. Muenchhoff, M.; Mairhofer, H.; Nitschko, H.; Grzimek-Koschewa, N.; Hoffmann, D.; Berger, A.; Rabenau, H.; Widera, M.; Ackermann, N.; Konrad, R.; et al. Multicentre comparison of quantitative PCR-based assays to detect Sars-CoV-2, Germany, March 2020. Eurosurveillance 2020, 25, 2001057. [CrossRef]

15. Iglói, Z.; Leven, M.; Abdel-Karem Abou-Nouar, Z.; Weller, B.; Matheeussen, V.; Coppens, J.; Koopmans, M.; Molenkamp, R. Comparison of commercial realtime reverse transcription PCR assays for the detection of Sars-CoV-2. J. Clin. Virol. 2020, 129, 104510. [CrossRef] [PubMed]

16. Vogels, C.B.F.; Brito, A.F.; Wyllie, A.L.; Fauver, J.R.; Ott, I.M.; Kalinich, C.C.; Petrone, M.E.; Casanovas-Massana, A.; Catherine Muenker, M.; Moore, A.J.; et al. Analytical sensitivity and efficiency comparisons of Sars-CoV-2 RT-qPCR primer-probe sets. Nat. Microbiol. 2020, 5, 1299-1305. [CrossRef] [PubMed]

17. Mögling, R.; Meijer, A.; Berginc, N.; Bruisten, S.; Charrel, R.; Coutard, B.; Eckerle, I.; Enouf, V.; Hungnes, O.; Korukluoglu, G.; et al. Delayed laboratory response to covid-19 caused by molecular diagnostic contamination. Emerg. Infect. Dis. 2020, $26,1944$. [CrossRef] [PubMed]

18. Wernike, K.; Keller, M.; Conraths, F.J.; Mettenleiter, T.C.; Groschup, M.H.; Beer, M. Pitfalls in Sars-CoV-2 PCR diagnostics. Transbound. Emerg. Dis. 2020, 68, 253-257. [CrossRef]

19. Hoffmann, B.; Depner, K.; Schirrmeier, H.; Beer, M. A universal heterologous internal control system for duplex real-time RT-PCR assays used in a detection system for pestiviruses. J. Virol. Methods 2006, 136, 200-209. [CrossRef] [PubMed]

20. Kralik, P.; Ricchi, M. A basic guide to real time PCR in microbial diagnostics: Definitions, parameters, and everything. Front. Microbiol. 2017, 8, 108. [CrossRef] [PubMed]

21. Corman, V.M.; Landt, O.; Kaiser, M.; Molenkamp, R.; Meijer, A.; Chu, D.K.W.; Bleicker, T.; Brunink, S.; Schneider, J.; Schmidt, M.L.; et al. Detection of 2019 novel coronavirus (2019-ncov) by real-time RT-PCR. Eurosurveillance 2020, 25, 2000045. [CrossRef]

22. Wernike, K.; Hoffmann, B.; Kalthoff, D.; König, P.; Beer, M. Development and validation of a triplex real-time PCR assay for the rapid detection and differentiation of wild-type and glycoprotein E-deleted vaccine strains of bovine herpesvirus type 1. J. Virol. Methods 2011, 174, 77-84. [CrossRef]

23. Griffin, S. Covid-19: Second wave death rate is doubling fortnightly but is lower and slower than in March. BMJ 2020, $371, \mathrm{~m} 4092$. [CrossRef]

24. Grech, V.; Cuschieri, S. Covid-19: A global and continental overview of the second wave and its (relatively) attenuated case fatality ratio. Early Hum. Dev. 2020, 105211. [CrossRef]

25. ProMED-Mail. Covid-19 Update (232): South Africa, USA Delta var., India, Israel, Who, Global. Archive Number: 20210706.8499538. 2021. Available online: Http:/ /www.Promedmail.Org (accessed on 6 July 2021).

26. Fereidouni, S.R.; Harder, T.C.; Gaidet, N.; Ziller, M.; Hoffmann, B.; Hammoumi, S.; Globig, A.; Starick, E. Saving resources: Avian influenza surveillance using pooled swab samples and reduced reaction volumes in real-time RT-PCR. J. Virol. Methods 2012, 186, 119-125. [CrossRef] [PubMed]

27. Batten, C.A.; Sanders, A.J.; Bachanek-Bankowska, K.; Bin-Tarif, A.; Oura, C.A. Bluetongue virus: European community proficiency test (2007) to evaluate ELISA and RT-PCR detection methods with special reference to pooling of samples. Vet. Microbiol. 2009, 135, 380-383. [CrossRef] [PubMed]

28. Flannery, J.; Rajko-Nenow, P.; Hicks, H.; Hill, H.; Gubbins, S.; Batten, C. Evaluating the most appropriate pooling ratio for EDTA blood samples to detect bluetongue virus using real-time RT-PCR. Vet. Microbiol. 2018, 217, 58-63. [CrossRef]

29. Kennedy, J.A.; Mortimer, R.G.; Powers, B. Reverse transcription-polymerase chain reaction on pooled samples to detect bovine viral diarrhea virus by using fresh ear-notch-sample supernatants. J. Vet. Diagn. Investig. 2006, 18, 89-93. [CrossRef] [PubMed] 
30. Hogan, C.A.; Sahoo, M.K.; Pinsky, B.A. Sample pooling as a strategy to detect community transmission of Sars-CoV-2. JAMA 2020, 323, 1967-1969. [CrossRef]

31. Aragón-Caqueo, D.; Fernández-Salinas, J.; Laroze, D. Optimization of group size in pool testing strategy for Sars-CoV-2: A simple mathematical model. J. Med. Virol. 2020, 92, 1988-1994. [CrossRef]

32. Ben-Ami, R.; Klochendler, A.; Seidel, M.; Sido, T.; Gurel-Gurevich, O.; Yassour, M.; Meshorer, E.; Benedek, G.; Fogel, I.; OiknineDjian, E.; et al. Large-scale implementation of pooled RNA extraction and RT-PCR for Sars-CoV-2 detection. Clin. Microbiol. Infect. 2020, 26, 1248-1253. [CrossRef]

33. Torres, I.; Albert, E.; Navarro, D. Pooling of nasopharyngeal swab specimens for Sars-CoV-2 detection by RT-PCR. J. Med. Virol. 2020. [CrossRef]

34. Wacharapluesadee, S.; Kaewpom, T.; Ampoot, W.; Ghai, S.; Khamhang, W.; Worachotsueptrakun, K.; Wanthong, P.; Nopvichai, C.; Supharatpariyakorn, T.; Putcharoen, O.; et al. Evaluating the efficiency of specimen pooling for PCR-based detection of covid-19. J. Med. Virol. 2020, 92, 2193-2199. [CrossRef]

35. Williamson, E.J.; Walker, A.J.; Bhaskaran, K.; Bacon, S.; Bates, C.; Morton, C.E.; Curtis, H.J.; Mehrkar, A.; Evans, D.; Inglesby, P.; et al. Factors associated with covid-19-related death using opensafely. Nature 2020, 584, 430-436. [CrossRef]

36. Mallapaty, S. The coronavirus is most deadly if you are older and male-New data reveal the risks. Nature 2020, 585, 16-17. [CrossRef] [PubMed]

37. Zou, L.; Ruan, F.; Huang, M.; Liang, L.; Huang, H.; Hong, Z.; Yu, J.; Kang, M.; Song, Y.; Xia, J.; et al. Sars-CoV-2 viral load in upper respiratory specimens of infected patients. N. Engl. J. Med. 2020, 382, 1177-1179. [CrossRef] [PubMed]

38. Weiss, A.; Jellingsø, M.; Sommer, M.O.A. Spatial and temporal dynamics of Sars-CoV-2 in covid-19 patients: A systematic review and meta-analysis. EBioMedicine 2020, 58, 102916. [CrossRef] [PubMed]

39. Wölfel, R.; Corman, V.M.; Guggemos, W.; Seilmaier, M.; Zange, S.; Müller, M.A.; Niemeyer, D.; Jones, T.C.; Vollmar, P.; Rothe, C.; et al. Virological assessment of hospitalized patients with covid-2019. Nature 2020, 581, 465-469. [CrossRef] [PubMed]

40. Huang, C.G.; Lee, K.M.; Hsiao, M.J.; Yang, S.L.; Huang, P.N.; Gong, Y.N.; Hsieh, T.H.; Huang, P.W.; Lin, Y.J.; Liu, Y.C.; et al. Culture-based virus isolation to evaluate potential infectivity of clinical specimens tested for Covid-19. J. Clin. Microbiol. 2020, 58, e01068-20. [CrossRef]

41. Cevik, M.; Kuppalli, K.; Kindrachuk, J.; Peiris, M. Virology, transmission, and pathogenesis of Sars-CoV-2. BMJ 2020, 371 , m3862. [CrossRef]

42. Van Kampen, J.J.A.; van de Vijver, D.; Fraaij, P.L.A.; Haagmans, B.L.; Lamers, M.M.; Okba, N.; van den Akker, J.P.C.; Endeman, H.; Gommers, D.; Cornelissen, J.J.; et al. Duration and key determinants of infectious virus shedding in hospitalized patients with coronavirus disease-2019 (covid-19). Nat. Commun. 2021, 12, 267. [CrossRef] 